University of Nebraska - Lincoln

DigitalCommons@University of Nebraska - Lincoln

\title{
Nationally Coordinated Evaluation of Soil Nitrogen Mineralization Rate using a Standardized Aerobic Incubation Protocol
}

\author{
T. S. Griffin \\ USDA-ARS, tim.griffin@ars.usda.gov
}

C. W. Honeycutt

USDA-ARS

S. L. Albrecht

USDA-ARS

K. R. Sistani

USDA-ARS

H. A. Torbert

USDA-ARS

See next page for additional authors

Follow this and additional works at: https://digitalcommons.unl.edu/usdaarsfacpub

Part of the Agricultural Science Commons

Griffin, T. S.; Honeycutt, C. W.; Albrecht, S. L.; Sistani, K. R.; Torbert, H. A.; Wienhold, B. J.; Woodbury, B. L.; Hubbard, R. K.; and Powell, J. M., "Nationally Coordinated Evaluation of Soil Nitrogen Mineralization Rate using a Standardized Aerobic Incubation Protocol" (2008). Publications from USDA-ARS / UNL Faculty. 607.

https://digitalcommons.unl.edu/usdaarsfacpub/607

This Article is brought to you for free and open access by the U.S. Department of Agriculture: Agricultural Research Service, Lincoln, Nebraska at DigitalCommons@University of Nebraska - Lincoln. It has been accepted for inclusion in Publications from USDA-ARS / UNL Faculty by an authorized administrator of DigitalCommons@University of Nebraska - Lincoln. 


\section{Authors}

T. S. Griffin, C. W. Honeycutt, S. L. Albrecht, K. R. Sistani, H. A. Torbert, B. J. Wienhold, B. L. Woodbury, R. K. Hubbard, and J. M. Powell 


\title{
Nationally Coordinated Evaluation of Soil Nitrogen Mineralization Rate using a Standardized Aerobic Incubation Protocol
}

\author{
T. S. Griffin, ${ }^{1}$ C. W. Honeycutt, ${ }^{1}$ S. L. Albrecht, ${ }^{2}$ \\ K. R. Sistani, ${ }^{3}$ H. A. Torbert ${ }^{4}$ B. J. Wienhold, ${ }^{5}$ \\ B. L. Woodbury, ${ }^{6}$ R. K. Hubbard, ${ }^{7}$ and J. M. Powell ${ }^{8}$ \\ ${ }^{1}$ United States Department of Agriculture, Agricultural Research Service, \\ Orono, Maine, USA \\ ${ }^{2}$ United States Department of Agriculture, Agricultural Research Service, \\ Pendleton, Oregon, USA \\ ${ }^{3}$ United States Department of Agriculture, Agricultural Research Service, \\ Bowling Green, Kentucky, USA \\ ${ }^{4}$ United States Department of Agriculture, Agricultural Research Service, \\ Auburn, Alabama, USA \\ ${ }^{5}$ United States Department of Agriculture, Agricultural Research Service, \\ Lincoln, Nebraska, USA \\ ${ }^{6}$ United States Department of Agriculture, Agricultural Research Service, \\ Clay Center, Nebraska, USA \\ ${ }^{7}$ United States Department of Agriculture, Agricultural Research Service, \\ Tifton, Georegia, USA \\ ${ }^{8}$ United States Department of Agriculture, Agricultural Research Service, \\ Madison, Wisconsin, USA
}

\begin{abstract}
Aerobic incubation methods have been widely used to assess soil nitrogen (N) mineralization, but standardized protocols are lacking. A single silt loam soil (Catlin silt loam; fine-silty, mixed, superactive, mesic, Oxyaquic Arguidoll) was
\end{abstract}

Received 10 April 2006, Accepted 2 December 2006

Mention of trade names or commercial products in this article is solely for the purpose of providing specific information and does not imply recommendation or endorsement by the U.S. Department of Agriculture.

Address correspondence to T. S. Griffin, United States Department of Agriculture, Agricultural Research Service (USDA-ARS), Orono, ME 04469, USA. E-mail: tim. griffin@ars.usda.gov 
subjected to aerobic incubation at six USDA-ARS locations using a standardized protocol. Incubations were conducted at multiple temperatures, which were combined based on degree days (DD). Soil water was maintained at $60 \%$ waterfilled pore space (WFPS; constant) or allowed to fluctuate between 60 and 30\% WFPS (cycle). Soil subsamples were removed periodically and extracted in $2 \mathrm{M}$ potassium chloride $(\mathrm{KCl})$; nitrate $\left(\mathrm{NO}_{3}\right)$ and ammonium $\left(\mathrm{NH}_{4}\right)$ concentrations in extracts were determined colorimetrically. For each location, the rate of soil organic-matter $\mathrm{N}$ (SOMN) mineralization was estimated by regressing soil inorganic $\mathrm{N}\left(\mathrm{N}_{\mathrm{i}}\right)$ concentration on $\mathrm{DD}$, using a linear (zero-order) model. When all data were included, the mineralization rate from four datasets was not statistically different, with a rate equivalent to $0.5 \mathrm{mg} \mathrm{N} \mathrm{kg}^{-1}$ soil day ${ }^{-1}$. Soil incubated at two locations exhibited significantly higher SOMN mineralization rates. To assess whether this may have been due to pre-incubation conditions, time-zero data were excluded and regression analysis was conducted again. Using this data subset, SOMN mineralization from five (of six) datasets was not significantly different. Fluctuating soil water reduced $\mathrm{N}$-mineralization rate at two (of four) locations by an average of 50\%; fluctuating soil water content also substantially increased variability. This composite dataset demonstrates that standardization of aerobic incubation methodology is possible.

Keywords: mineralization, nitrogen, soil organic matter

\section{INTRODUCTION}

There are numerous methodological approaches to estimating the amount of nitrogen $(\mathrm{N})$ mineralized from soil organic-matter $\mathrm{N}$ (SOMN), crop residues, or applied amendments. Field experiments vary in scale from enclosed microplot cyclinders containing less than $1 \mathrm{~kg}$ of soil (Eghball 2000; Hatch, Jarris, and Pakinson 1998) to field-scale assessments of crop $\mathrm{N}$ response (Fox and Piekielek 1984; Fox, Myers, and Vallis 1990; Mulvaney et al. 2001). Laboratory approaches are similarly variable, especially in the time required to implement. These range from rapid, simple chemical extractions (Gianello and Bremner 1986; Keeney and Bremner 1966) to aerobic incubations of 100- to 300-days duration (Griffin and Honeycutt 2000; Honeycutt, Potaro, and Halteman 1991; Stanford and Smith 1972).

Aerobic incubation often serves as the validation phase for more rapid chemical or biological methods. Most aerobic incubation experiments have common features, including maintenance of optimal soil water status, controlled (and usually constant) temperature, and periodic sampling over time to estimate $\mathrm{N}$ transformation rate(s). Although there have been several standardized protocols published (Bundy and Meisinger 1994; Robertson et al. 1999), there is significant variation in the details of aerobic incubations, including leached vs. nonleached samples (Honeycutt, Zibilske, and Clapham, 1988; Wienhold and Halvorson 1999); field-moist vs. dried and 
ground soil (Cabrera and Kissel 1988a), homogenized soil vs. undisturbed soil cores (Griffin and Honeycutt 2000; Marion and Black 1987), and differences in the duration of incubation, all of which influence the rate and extent of $\mathrm{N}$ mineralization.

Honeycutt et al. (2005) recently described an aerobic incubation protocol that was used by USDA-ARS scientists at six U.S. locations in a nationally coordinated project to predict manure $\mathrm{N}$ availability. Although the primary focus was to assess the effect of soil type, temperature, soil water, and manure $\mathrm{N}$ characteristics on $\mathrm{N}$ availability (Griffin, Honeycutt, and $\mathrm{He}$ 2002; Honeycutt, Griffin, and He 2005), it represents the first effort to assess the standardization of aerobic incubation methods across sites. Significantly, a common soil from Illinois (Catlin silt loam; fine, silty, mixed, superactive, mesic, Oxyaquic Argiudoll; Table 1) was incubated at each location as a control, offering a unique opportunity to compare SOMN mineralization rates from a single soil incubated at different locations. The results of this comparison are reported here.

\section{MATERIALS AND METHODS}

The incubation protocol is described in detail in Honeycutt et al. (2005), and applications of this protocol are published in Griffin, Honeycutt, and $\mathrm{He}$ (2002) and Honeycutt, Griffin, and He (2005). The core treatment across locations included a combination of two to four locally relevant incubation temperatures (Table 2), with soil incubated at constant soil water content ( $60 \%$ waterfilled pore space, WFPS). All locations had 18 and $25^{\circ} \mathrm{C}$ incubation temperatures in common. Four locations also contributed data for soil that was subjected to repeated cycles of drying to $30 \%$ WFPS and rewetting to $60 \%$ WFPS.

For each temperature-soil water combination, $250 \mathrm{~g}$ of air-dried Catlin silt loam soil was placed in triplicate 1-L glass jars, and water was added to

Table 1. Characteristics of Catlin silt loam soil used in incubation experiments at six USDA-ARS locations

\begin{tabular}{lc}
\hline Parameter & Value \\
\hline Soil $\mathrm{pH}$ & 7.0 \\
$\mathrm{CEC}\left(\mathrm{meq} 100 \mathrm{~g}^{-1}\right)$ & 20.1 \\
Total C $\left(\mathrm{g} \mathrm{kg}^{-1}\right)$ & 32.7 \\
Total N $\left(\mathrm{g} \mathrm{kg}^{-1}\right)$ & 1.8 \\
$\mathrm{~K}\left(\mathrm{~kg} \mathrm{ha}^{-1}\right.$ equiv. $)$ & 771 \\
$\mathrm{P}\left(\mathrm{kg} \mathrm{ha}^{-1}\right.$ equiv. $)$ & 47 \\
Sand $\left(\mathrm{g} \mathrm{kg}^{-1}\right)$ & 220 \\
Silt $\left(\mathrm{g} \mathrm{kg}^{-1}\right)$ & 630 \\
Clay $\left(\mathrm{g} \mathrm{kg}^{-1}\right)$ & 150 \\
\hline
\end{tabular}


bring soil water content to approximately 50\% WFPS. The soil was gently packed to a density of $1.2 \mathrm{~g} \mathrm{~cm}^{-3}$ and pre-incubated for a minimum of 7 days The jars were capped except for $1 \mathrm{~h} \mathrm{~d}^{-1}$ for aeration. Each jar was pre-incubated and incubated at the same temperature.

At the start of the incubation period $(t=0)$, water was added to increase soil water to $60 \%$ WFPS in all jars, regardless of soil water treatment. A single $1.5-\mathrm{cm}$-diameter core was taken through the soil layer in each jar. From this soil sample, a 5-g subsample was weighed, dried at $105^{\circ} \mathrm{C}$, and reweighed to measure gravimetric soil water content. Another 5 -g subsample was extracted in $50 \mathrm{~mL} 2 \mathrm{M}$ potassium chloride $(\mathrm{KCl})$ for $60 \mathrm{~min}$, then either centrifuged or filtered to obtain a clear extract. The extract was either analyzed immediately for ammonium $\left(\mathrm{NH}_{4}\right)+$ nitrate $\left(\mathrm{NO}_{3}\right)$ or frozen until analysis. All locations maintained a complete set of soils with soil water content maintained at $60 \%$ WFPS by weighing and adding water at 1 to 3 -day intervals for the duration of the incubation. At four locations, another set of jars was allowed to slowly dry from 60 to $30 \%$ WFPS. When these jars reached the 30\% WFPS target, they were rewetted to $60 \%$ WFPS and immediately sampled for inorganic $\mathrm{N}\left(\mathrm{N}_{\mathrm{i}}\right)$ as described previously. The corresponding constant soil water treatment was sampled at the same time. The length of the incubation period was equal to four drying-rewetting cycles and varied considerably by location and temperature (see Results and Discussion).

Soil inorganic $\mathrm{N}$ concentration for each location was standardized across temperatures using the degree day (DD) or thermal unit approach of Honeycutt, Zibilske, and Clapham (1988) and Griffin and Honeycutt (2000). Preliminary evaluation of soil $\mathrm{N}_{\mathrm{i}}$ concentration indicated that $\mathrm{N}$ mineralization was a linear function of DD; thus, mineralization rate $\left(N_{\text {min }}\right)$ was estimated as the slope of regression Equation (1);

$$
\mathrm{N}_{\mathrm{i}} \text { conc. }\left(\mathrm{mg} \mathrm{kg}^{-1} \text { soil }\right)=A+N_{\min } \times \mathrm{DD}
$$

Table 2. List of treatments included for aerobic incubation of Catlin silt loam soil at six USDA-ARS locations

\begin{tabular}{lll}
\hline Location & $\begin{array}{c}\text { Incubation temperatures } \\
\text { included }\end{array}$ & \multicolumn{1}{c}{$\begin{array}{c}\text { Soil water treatments } \\
\text { included }\end{array}$} \\
\hline Alabama & 11,18, and $25^{\circ} \mathrm{C}$ & Constant \\
Maine & 11,18, and $25^{\circ} \mathrm{C}$ & Constant and cycling \\
Mississippi & 18 and $25^{\circ} \mathrm{C}$ & Constant \\
Nebraska 1 & $11,18,25$, and $32^{\circ} \mathrm{C}$ & Constant and cycling \\
Nebraska 2 & $11,18,25$, and $32^{\circ} \mathrm{C}$ & Constant and cycling \\
Oregon & 11,18, and $25^{\circ} \mathrm{C}$ & Constant and cycling \\
\hline
\end{tabular}


where $A$ is soil $\mathrm{N}_{\mathrm{i}}$ concentration at $t=0$, and $N_{\min }$ is mineralization rate. This was done for each replicate individually, resulting in three estimates of $\mathrm{N}$-transformation rate for each location. Analysis of variance (ANOVA) was then used to identify significant differences in $N_{\min }$ between locations. Where significant differences existed, a least significant difference (LSD) was calculated at 5\% level of probability. This was first done using all data points from each location and then was repeated, excluding the $t=0$ data to remove potential residual differences due to processing and pre-incubation at the six locations.

\section{RESULTS AND DISCUSSION}

The length of the incubation period, for each combination of temperature and location, was not predetermined in the incubation protocol. Rather, it was equal to the time required to complete four drying-rewetting cycles in the cycling soil water treatment, with the desired outcome being a relatively slow drying of the soil in this treatment. As discussed in Honeycutt et al. (2005), this was accomplished by drilling three equally spaced holes in the lids of jars in the cycling soil water treatment (as opposed to leaving the jars uncovered, which results in rapid soil drying). Clearly, incubation temperature was expected to impact the soil drying rate and thus the length of the incubation. As shown by Griffin, Honeycutt, and He (2002), a sandy loam soil included in this same incubation experiment dried to 30\% WFPS in 27, 18, and 12 days at incubation temperatures of 11,18 , and $25^{\circ} \mathrm{C}$, respectively (Figure 1).

Temperature effects on mineralization of SOMN can easily be standardized by the application of thermal units or DD, as has been shown numerous times (Griffin and Honeycutt 2000; Griffin, Honeycutt, and He 2002; Honeycutt 1994; Honeycutt, Zibilske, and Clapham 1988; Honeycutt, Potaro, and Halteman 1991; Honeycutt, Clapham, and Leach 1994). The application of DD to $\mathrm{N}$ mineralization is shown in Figure 2, from the incubation of the Catlin silt loam soil at the Maine location. In this case, net $\mathrm{N}$ mineralization is a linear function of $\mathrm{DD}\left(\mathrm{R}^{2}=0.83\right)$, similar to the results of Addiscott (1983), Dendooven, Merckx, and Vlassak (1995) and Mary et al. (1999). Although some of the datasets used here exhibited slight curvilinearity, no attempt was made to apply the standard statistical model of Stanford and Smith (1972) (Equation 2).

$$
\mathrm{N}_{\mathrm{i}} \text { conc. }\left(\mathrm{mg} \mathrm{kg}^{-1} \text { soil }\right)=N_{0} \times\left(1-e^{\left(-k^{\times} \mathrm{DD}\right)}\right)
$$

This model allows the simultaneous estimation of a mineralization rate constant $(k)$ and the size of the potentially mineralizable $\mathrm{N}$ pool $\left(N_{0}\right)$. Although there are numerous examples of this exponential model being applied to relatively short incubations (Groot and Houba 1995; Robertson 


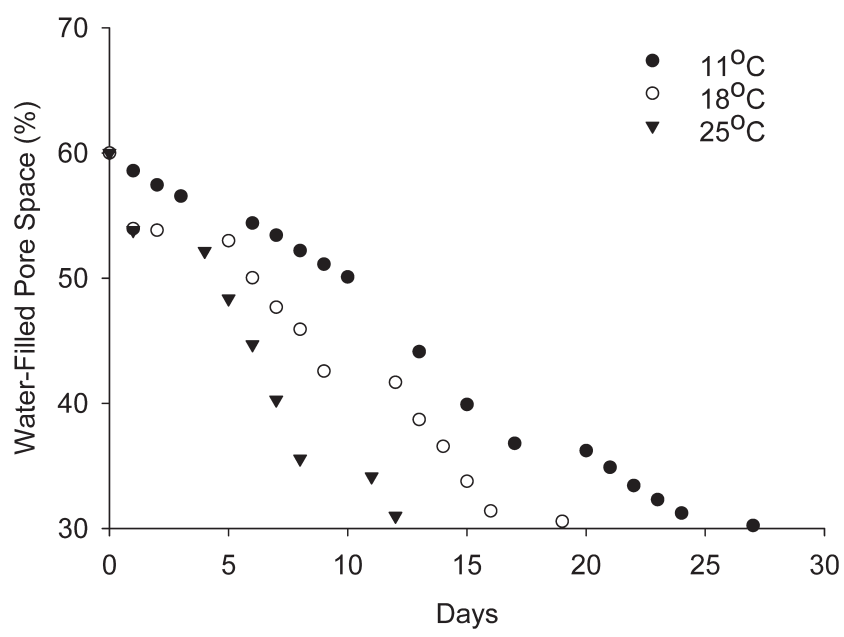

Figure 1. Average drying rate of sandy loam soil at three incubation temperatures (from Griffin, Honeycutt, and He 2002).

et al. 1988), in all likelihood none of the incubations reported here were sufficiently long to reliably estimate these two parameters, as discussed by Molina Clapp, and Larson (1980) and Cabrera and Kissel (1988b). There was only one incubation that was longer than 168 days (177 days at the Alabama location) that is considered minimal for applying the model of Stanford and Smith

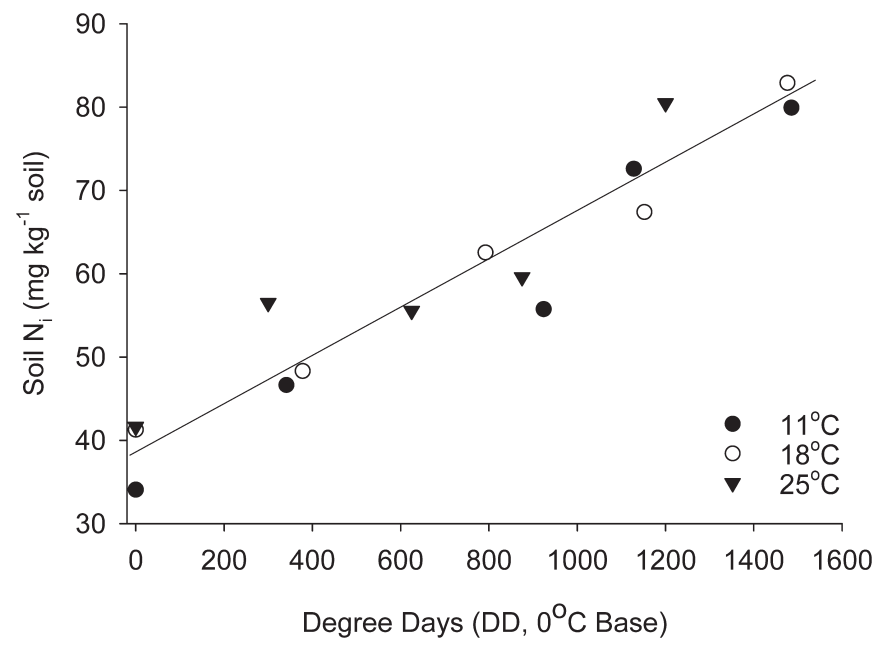

Figure 2. Cumulative net $\mathrm{N}$-mineralization from Catlin silt loam soil incubated at three temperatures in Orono, Maine. 
(1972). However, because this incubation was conducted at $11^{\circ} \mathrm{C}$, it was equivalent to only 78 days at a temperature of $25^{\circ} \mathrm{C}$.

The difference in drying rate between locations was larger than expected, presumably because of differences in ambient relative humidity, which would directly affect soil drying rate. This resulted in substantial differences in the length of the incubation period across locations, even at the same incubation temperature. At $25^{\circ} \mathrm{C}$, the time required for completion of four dryingrewetting cycles varied from 27 to 93 days for incubations conducted in Oregon and Mississippi, respectively (Figure 3).

Analysis of variance on net $\mathrm{N}$-mineralization rate estimates indicated that there were significant differences between some locations. When all data points from the constant soil water treatment were included (Figure 4), there were two locations (Alabama and Mississippi) that had an average net mineralization of $0.040 \mathrm{mg} \mathrm{N} \mathrm{kg}^{-1}$ soil $\mathrm{DD}^{-1}$, and the other four locations (which were not significantly different from each other) had an average net mineralization rate of $0.0197 \mathrm{mg} \mathrm{N} \mathrm{kg}^{-1}$ soil $\mathrm{DD}^{-1}$. These would be approximately equivalent to rates of 1.00 and $0.50 \mathrm{mg} \mathrm{N} \mathrm{kg}^{-1}$ soil day ${ }^{-1}$, respectively, at a constant temperature of $25^{\circ} \mathrm{C}$.

The net mineralization rates shown in Figure 4 are similar to previous reports where SOMN mineralization followed zero-order kinetics. For example, Addiscott (1983) found that arable soil had a net mineralization rate of $0.40 \mathrm{mg} \mathrm{N} \mathrm{kg}^{-1}$ soil day ${ }^{-1}$ during aerobic incubation at $25^{\circ} \mathrm{C}$, with higher rates resulting from manure application or long-term grass stands.

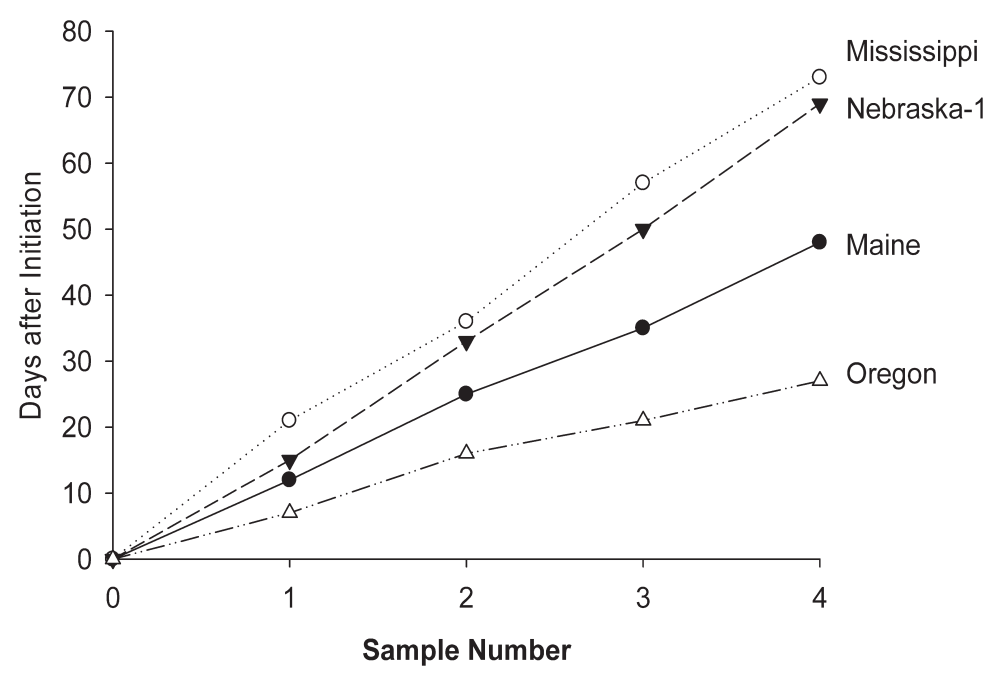

Figure 3. Differences in sampling intervals and duration of aerobic incubation at four locations. 


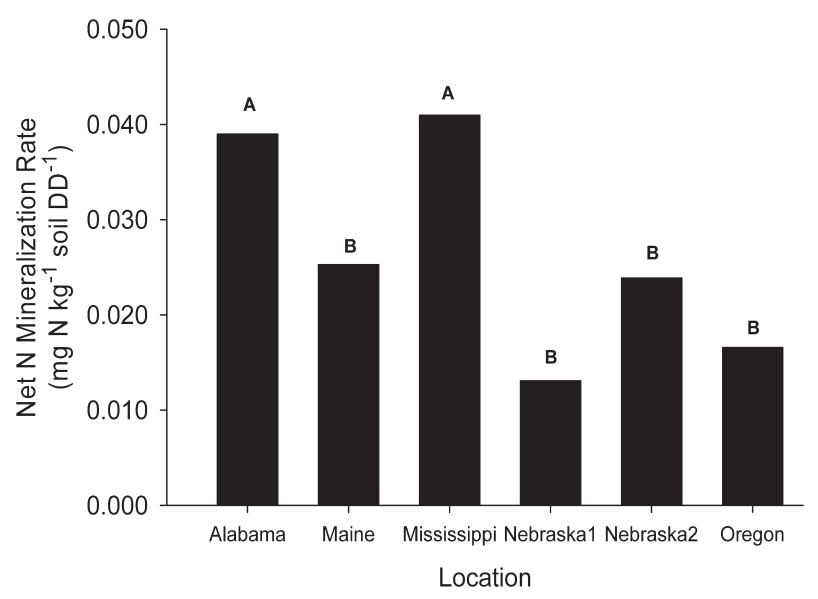

Figure 4. Net N-mineralization rate of Catlin silt loam soil incubated at six USDAARS locations.

Hassink (1994) found that net mineralization rates for short-term grass stands (1-2 years) ranged from 0.38 to $1.14 \mathrm{mg} \mathrm{N} \mathrm{kg}^{-1}$ soil day ${ }^{-1}$.

There are no extant comparisons of net $\mathrm{N}$-mineralization rates for a single soil, estimated from aerobic incubations conducted at different locations. It is possible that the higher net mineralization rates at two locations resulted from differences in the pre-incubation period. All locations initiated the pre-incubation using air-dried soil, and a flush of $\mathrm{N}$ (and carbon) mineralization would be expected upon rewetting (Birch 1964; Cabrera 1993; Franzluebbers et al. 2000). If the flush of $\mathrm{N}$ mineralization was not completed by the end of the pre-incubation period, it would result in more rapid apparent net $\mathrm{N}$ mineralization. To account for this possibility, we conducted the same regression analysis (to estimate net $\mathrm{N}$-mineralization rate), excluding the original $t=0$ data; this has the effect of lengthening the pre-incubation period by 175 to 480 $\mathrm{DD}$, depending on location and incubation temperature. As before, the mineralization rate $\left(N_{\text {min }}\right)$ was estimated for each replicate $\times$ temperature combination at each location, and differences were identified by ANOVA. The results of this comparison are shown in Figure 5. The mineralization rate from Nebraska $1\left(0.0079 \mathrm{mg} \mathrm{N} \mathrm{kg}^{-1}\right.$ soil $\left.\mathrm{DD}^{-1}\right)$ is significantly lower than three other locations (Alabama, Maine, and Mississippi). There are no significant differences among the other five locations, with an average net $\mathrm{N}$-mineralization rate of $0.0216 \mathrm{mg} \mathrm{N} \mathrm{kg}^{-1}$ soil $\mathrm{DD}^{-1}$, equivalent to $0.54 \mathrm{mg} \mathrm{N} \mathrm{kg}^{-1}$ soil day ${ }^{-1}$ at a constant temperature of $25^{\circ} \mathrm{C}$. The fact that the estimates of net $\mathrm{N}$-mineralization rate from Alabama and Mississippi locations are now similar in magnitude to three other locations (and approximately half of the previous estimate when all data were used) would seem to implicate differences in pre-incubation conditions. The cause of the lower 


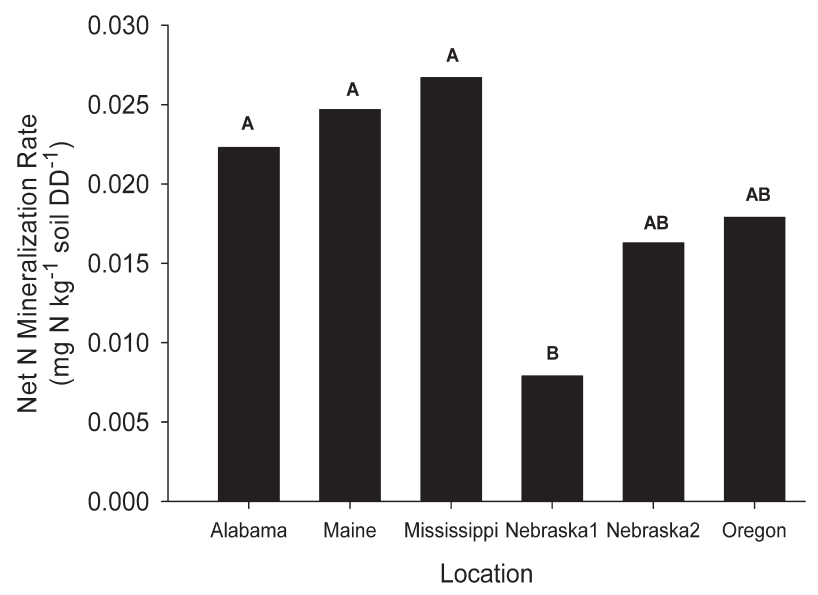

Figure 5. Net N-mineralization rate of Catlin silt loam soil incubated at six USDAARS locations, excluding data from time $=0$ extraction to account for pre-incubation effects.

estimates from Nebraska 1 location (including or excluding $t=0$ data) is not clear.

Four of the six locations (Maine, Nebraska 1, Nebraska 2, and Oregon) contributed data for both constant and cycling soil water treatments. These treatments were initially included in the protocol of Honeycutt et al. (2005) based on previous reports of mineralization flushes occurring when dry soil is rapidly wet to field capacity (Birch 1964; Cabrera 1993; Franzluebbers et al. 2000). Two substantial differences between our protocol and some of these earlier reports are the rate and extent of the drying; our soil was dried relatively slowly, and only to $30 \%$ WFPS (rather than to air-dry status). As pointed out by Griffin, Honeycutt, and He (2002), the dry-wet cycles implemented in this protocol did not result in a noticeable flush of $\mathrm{N}$ mineralization from applied swine slurry. Honeycutt, Griffin, and He (2005) drew similar conclusions for dairy manure $\mathrm{N}$, using the same protocol. The impact of these drying-wetting cycles on mineralization of SOMN is mixed, as shown in Figure 6. At two locations (Nebraska 1 and Oregon), fluctuating soil water during the incubation had no significant effect on estimates of net N-mineralization rate. At the other two locations (Nebraska 2 and Maine), the net $\mathrm{N}$-mineralization rate was reduced by 40 to $60 \%$ as a result of repeated drying and rewetting cycles. This reduction in net $\mathrm{N}$ mineralization from SOM is in agreement with numerous previous reports, including Cassman and Munns (1980), De Neve and Hofman (2002), and Sierra (1997), where soil water content was reduced to levels that might be expected under field conditions. It should also be noted that the experimental 


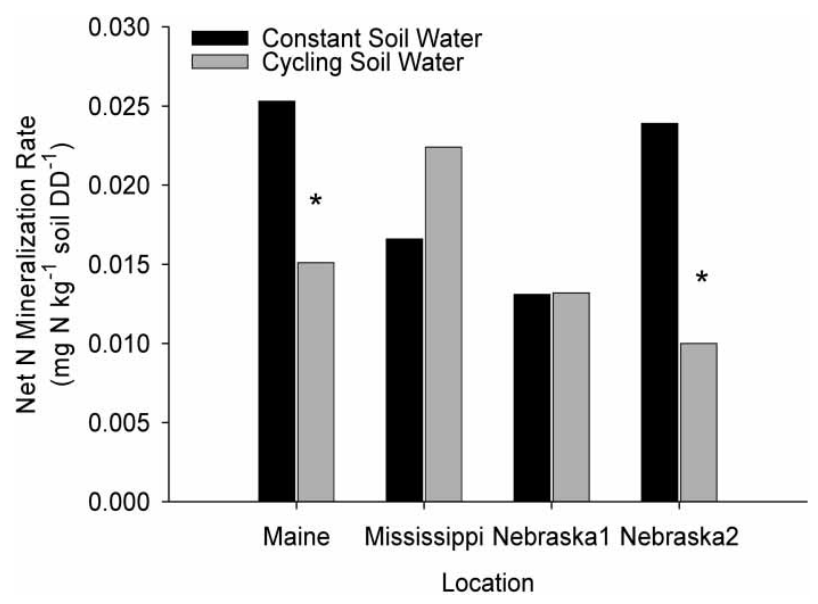

Figure 6. Comparison of constant and cycling soil water treatments on net N-mineralization rate of Catlin silt loam soil at four USDA-ARS locations (*indicates significant difference between soil water treatments at location).

variability in the cycling soil water treatment was three- to four-fold greater than in the constant soil water treatment.

\section{CONCLUSIONS}

Because aerobic incubation methods are widely used not only for evaluating soil $\mathrm{N}$ transformations but also for carbon and phosphorus cycling in soils, it is important to develop and test standardized methods. This standardization, like that of most soil-testing strategies, allows results to be compared from different locations and also allows larger datasets to be compiled. As was demonstrated with this study, it is possible to arrive at similar N-mineralization rate estimates from multiple locations. The similarity in $\mathrm{N}$-mineralization rate across five of six locations is encouraging, given that incubations were conducted at multiple temperatures and with two soil water treatments as part of the experimental design. Additionally, the experimental design resulted in substantial differences in the duration of the incubations, while still resulting in similar $\mathrm{N}$-mineralization rate estimates.

\section{REFERENCES}

Addiscott, T.M. (1983) Kinetics and temperature relationships of mineralization and nitrification in Rothamsted soils with differing histories. Soil Science, 34: 343-353.

Birch, H.F. (1964) Mineralization of plant nitrogen following alternate wet and dry conditions. Plant and Soil, 20: 43-49. 
Bundy, L.G. and Meisinger, J.J. (1994) Nitrogen availability indices. In Methods of Soil Analysis, Part 2: Microbiological and Biochemical Properties; Weaver, R.W. (ed.); Soil Science Society of America: Madison, Wisc., 951-984.

Cabrera, M.L. (1993) Modeling the flush of nitrogen mineralization caused by drying and rewetting soils. Soil Science Society of America, 57: 63-66.

Cabrera, M.L. and Kissel, D.E. (1988a) Evaluation of a method to predict nitrogen mineralized from soil organic matter under field conditions. Soil Science Society of America, 52: 1027-1031.

Cabrera, M.L. and Kissel, D.E. (1988b) Length of incubation time affects the parameter values of the double exponential model of nitrogen mineralization. Soil Science Society of America, 52: 1186-1187.

Cassman, K.G. and Munns, D.N. (1980) Nitrogen mineralization as affected by soil moisture, temperature, and depth. Soil Science Society of America, 44: 1233-1237.

De Neve, S. and Hofman, G. (2002) Quantifying soil water effects on nitrogen mineralization from soil organic matter and from fresh crop residues. Biology and Fertility of Soils, 35: 379-386.

Dendooven, L., Merckx, R., and Vlassak, K. (1995) Limitations of a calculated N mineralization potential in studies of the $\mathrm{N}$ mineralization process. Plant and Soil, 177: $175-181$.

Eghball, B. (2000) Nitrogen mineralization from field-applied beef cattle feedlot manure or compost. Soil Science Society of America, 64: 2024-2030.

Fox, R.H. and Piekielek, W.P. (1984) Relationships among anaerobically mineralized nitrogen, chemical indexes, and nitrogen availability to corn. Soil Science Society of America, 48: 1087-1090.

Fox, R.H., Myers, R.J.K., and Vallis, I. (1990) The nitrogen mineralization rate of legume residues in soil as influenced by their polyphenol, lignin, and nitrogen contents. Plant and Soil, 129: 251-259.

Franzluebbers, A.J., Haney, R.L., Honeycutt, C.W., Schomberg, H.H., and Hons, F.M. (2000) Flush of carbon dioxide following rewetting of dried soil relates to active organic pools. Soil Science Society of America, 64: 613-623.

Gianello, C. and Bremner, J.M. (1986) A simple chemical method for assessing potentially mineralizable organic nitrogen in soil. Communications in Soil Science and Plant Analysis, 17: 195-214.

Griffin, T.S. and Honeycutt, C.W. (2000) Using growing degree days to predict nitrogen availability from livestock manure. Soil Science Society of America Journal, 64: 1876-1882.

Griffin, T.S., Honeycutt, C.W., and He, Z. (2002) Effects of temperature, soil water status, and soil type on swine slurry nitrogen transformations. Biology and Fertility of Soils, 36: 442-446.

Groot, J.J.R. and Houba, V.J.G. (1995) A comparison of different indices for nitrogen mineralization. Biology and Fertility of Soils, 19: 1-9.

Hassink, J. (1994) Effects of soil texture and grassland management on soil organic C and $\mathrm{N}$ and rates of $\mathrm{C}$ and $\mathrm{N}$ mineralization. Soil Biology and Biochemistry, 26: $1221-1231$.

Hatch, D.J., Jarvis, S.C., and Parkinson, R.J. (1998) Concurrent measurements of net mineralization, nitrification, denitrification and leaching from field incubated soil cores. Biology and Fertility of Soils, 26: 323-330.

Honeycutt, C.W. (1994) Linking nitrogen mineralization and plant nitrogen demand with thermal units. In Soil Testing: Prospects for Improving Nutrient Recommendations; SSSA Special Publication 40. Soil Science Society of America: Madison, Wisc., 49-79. 
Honeycutt, C.W., Zibilske, L.M., and Clapham, W.M. (1988) Heat units for describing carbon mineralization and predicting net nitrogen mineralization. Soil Science Society of America, 52: 1346-1350.

Honeycutt, C.W., Potaro, L.J., and Halteman, W.A. (1991) Predicting nitrate formation from soil, fertilizer, crop residue, and sludge with thermal units. Journal of Environmental Quality, 20: 850-856.

Honeycutt, C.W., Clapham, W.M., and Leach, S.S. (1994) A functional approach to efficient nitrogen use in crop production. Ecological Modeling, 73: 51-61.

Honeycutt, C.W., Griffin, T.S., and He, Z. (2005) Manure nitrogen availability: Dairy manure in northeast and central US soils. Biological Agriculture and Horticulture, 23: $199-214$.

Honeycutt, C.W., Griffin, T.S., Wienhold, B.J., Eghball, B., Albrecht, S.L., Powell, J.M., Woodbury, B.L., Sistani, K.R., Hubbard, R.K., Torbert, H.A., Eigenberg, R.A., Wright, R.J., and Jawson, M.D. (2005) Protocols for nationally coordinated laboratory and field research on manure nitrogen mineralization. Communications in Soil Science and Plant Analysis, 36: 2807-2822.

Keeney, D.R. and Bremner, J.M. (1966) Comparison and evaluation of laboratory methods of obtaining an index of soil nitrogen availability. Agronomy Journal, 58: 498-503.

Marion, G.M. and Black, C.H. (1987) The effect of time and temperature on nitrogen mineralization in arctic tundra soils. Soil Science Society of America, 51: 1501-1508.

Mary, B., Beaudoin, N., Justes, E., and Machet, J.M. (1999) Calculation of nitrogen mineralization and leaching in fallow soil using a simple dynamic model. European Journal of Soil Science, 50: 549-566.

Molina, J.A.E., Clapp, C.E., and Larson, W.E. (1980) Potentially mineralizable nitrogen in soil: The simple exponential model does not apply for the first 12 weeks of incubation. Soil Science Society of America, 44: 442-443.

Mulvaney, R.L., Khan, S.A., Hoeft, R.G., and Brown, H.M. (2001) A soil organic nitrogen fraction that reduces the need for nitrogen fertilization. Soil Science Society of America Journal, 65: 1164-1172.

Robertson, G.P., Wedin, D., Groffman, P.M., Blair, J.M., Holland, E.A., Nadelhoffer, K.J., and Harris, D. (1999) Soil carbon and nitrogen availability: Nitrogen mineralization, nitrification, and soil respiration potentials. In Standard Soil Methods for Long-Term Ecological Research; Robertson, G.P., Coleman, D.C., Bledsoe, C.S. and Sollins, P. (eds.); Oxford University Press: New York, 258-271.

Robertson, K., Schnürer, J., Clarholm, M., Bonde, T.A., and Rosswall, T. (1988) Microbial biomass in relation to $\mathrm{C}$ and $\mathrm{N}$ mineralization during laboratory incubations. Soil Biology and Biochemistry, 20: 281-286.

Sierra, J. (1997) Temperature and soil moisture dependence of N mineralization in intact soil cores. Soil Biology and Biochemistry, 29: 1557-1563.

Stanford, G. and Smith, S.J. (1972) Nitrogen mineralization potentials of soils. Soil Science Society of America, 36: 465-472.

Wienhold, B.J. and Halvorson, A.D. (1999) Nitrogen mineralization responses to cropping, tillage, and nitrogen rate in the northern great plains. Soil Science Society of America, 63: 192-196. 